\title{
Social Capital and Social-Ecological Resilience in the Asteroussia Mountains, Southern Crete, Greece
}

\author{
Thanasis Kizos $^{1}$, Vassilis Detsis ${ }^{2}$, Theodoros Iosifides ${ }^{1}$ and Minas Metaxakis ${ }^{1}$
}

\begin{abstract}
Social-ecological resilience (SER) expresses the capacity of a social-ecological system to adapt and transform. We investigated the ways in which different types and transformations of social capital influence the SER of a region. The study area, the Asteroussia Mountains in southern Crete, Greece, is a typical semiarid hilly/mountainous area of the eastern Mediterranean in which land degradation is one of the most important issues in land management, mostly related to overgrazing because of the growing size of the flocks of sheep and goats. The approach followed was qualitative, with in-depth interviews with a small number of key stakeholders in the area. The findings indicate many important changes in the area in terms of its production, economy, and society, i.e., from a "semiarid husbandry" period during the 1950s to the early 1980s, through a transition period lasting until the end of 1980 s, to a new state, the "subsidized husbandry" period, abruptly terminated in 2008 by the ongoing economic crisis. These changes correspond to important changes in social capital and very low levels of wider social trust among stockbreeders, while trust toward other forms of collective action at the local/regional level is also limited. Agricultural subsidies in the 1980s and onward seemed to be an important "vehicle" for this change. Another important factor is related to external inputs and cash availability. The most serious negative impact of all these changes seems to be the abandonment of long-term care for the land. Primary producers ceased to associate their income with land quality, and this appears to be one important reason, among others, for the intensification of grazing densities and the abandonment of practices that considered vegetation and soil quality.
\end{abstract}

Key Words: Crete; Greece; land degradation and desertification; social-ecological resilience; social-ecological system

\section{INTRODUCTION}

Most of the applied research on social-ecological systems (SESs), coupled systems of people and nature (Folke et al. 2010), has focused on the economic and ecological aspects of the interactions that shape them; whereas the role of social factors, and of social capital in particular, has been relatively under-researched (Crane 2010, Davidson 2010). Social capital concerns the characteristics, properties, and quality of social networks, within and through which social actors pursue their activities (Iosifides et al. 2007). Its main features are social trust, social norms, cultural perceptions and values, and the character of social networks (Jones et al. 2008, Jackson 2009). Filed (2003) distinguishes three types of social capital: bonding, bridging, and linking. Bonding capital refers to relations within social groups, bridging refers to relations among different social groups, and linking refers to relations among individuals and groups that occupy different positions in social hierarchies (Larsen et al. 2004).

Social, economic, and ecological processes act on different hierarchical scales at which SESs are located. Social processes, which require longer timescales to become important, are sometimes overlooked (Dearing et al. 2010). Such processes cannot be easily detected from previous published research, are rarely explicit in historic data, and, being qualitative, tend to be loosely discussed and associated with ecological and economic processes. This is especially true for social capital, which mediates the relationship between natural capital and the diverse capitals of human origin, i.e., economic, financial, physical, landesque, cultural, institutional, and so forth. Grumbine (1994) has argued that the preservation of the integrity of ecosystems, and thus of their ability to provide services, relies heavily, apart from their intrinsic mechanisms to cope with stress and perturbations, on the ability and the will of social groups to make decisions on their own well-being and the natural environment on which they rely.
We sought to investigate the role of social capital in the resilience of an SES. More specifically, we explored how changes within and between different types of social capital affect the socialecological resilience (SER) of an SES. The principal research question was whether resilience-threatening shifts between different states of SESs are attributable to changes in slow social variables, especially within and between different types of social capital, or attributable to their persistence in altered socioeconomic environments. We have based our study on empirical findings from the Asteroussia Mountains in southern Crete, Greece, an area dominated by livestock farming. The analysis focuses on processes that connect people and social groups to each other, i.e., the social capital, and how they relate to the natural environment and utilize its resources.

\section{RATIONALE AND BACKGROUND}

The meaning of SER has evolved from the concept of "resilience," which originated in the field of ecology, within which it has acquired a large number of uses and definitions revolving around the capacity of ecosystems to persist following a perturbation (Grimm and Wissel 1997). For SESs, it is defined as "the capacity of a system to absorb disturbance and reorganize while undergoing change so as to still retain essentially the same function, structure, identity, and feedbacks" (Walker et al. 2004). Originally, the resilience discourse left out the question of whether a certain state of a system, apart from being resilient, is desirable or not, and for whom, relatively untouched. Although early warnings were provided that science can outline options but cannot provide the correct answer as to which of them is "best" without regarding social criteria (Grumbine 1994), normative questions only lately became more explicit (Cote and Nightingale 2012, Strunz 2012) through the "resilience-thinking" approach (Folke et al. 2010). 
The concept of resilience sensu stricto is linked to the distinction between persistence of a system in a given state and its transformation to another state. Transitions between states occur when a threshold is crossed, in which case positive feedback processes make the crossing irreversible (Walker et al. 2004, Scheffer et al. 2012). Thresholds are usually associated with "slow" variables (Scheffer et al. 2003, Walker et al. 2004, Reynolds et al. 2007, 2011). Although most studied threshold crossings associated with system transitions come from the ecological domain, there is no theoretical constraint as to the domain from which the thresholds originate (Folke et al. 2010).

Regions dominated by grazing commonly suffer from resilience loss attributable to unsustainable practices combined with unfavorable environmental conditions. The processes affecting resilience of the SES of an area dominated by animal husbandry in southern Crete is our focus. Grazing lands in Crete have generally been reported to suffer from degradation of vegetation cover in recent decades (Hostert et al. 2003); counterexamples have also been reported (e.g., Grove and Rackham, 2001). There is a general agreement that declining vegetation cover occurring in various areas of Crete is attributable to increasing flock size, after 1960 at least, which was further enhanced by subsidies from the mid-1980s onward (Lyrintzis and Papanastasis 1995, Hostert et al. 2003, Lorent et al. 2009). The mechanism that connects increased flock size and vegetation degradation is not clear because of the complex interplay of different factors at different scales. Hostert et al. (2003) identified the more intensive degradation patterns in the Psiloritis massif in central Crete in the areas most favorable for vegetation growth. This fact led them to assume that the most productive areas were subject to disproportionately greater grazing pressures because they were preferred by stockbreeders. The authors suggested that an accurate understanding of the causal connections requires lower spatial-level information like roaming patterns, species identities, and farming styles. At the farm level, Lorent et al. (2009) failed to establish a link between animal numbers and vegetation cover trends. They identified only a negative relationship between intensity of imported fodder and vegetation degradation, while degradation was found to depend on the geologic substrate as well. Things are further complicated because increased vegetation cover might mean less available forage and less biological diversity (Papanastasis and Chouvardas 2005). All in all, the intuitively straightforward relationship between animal numbers and degradation seems well established in general. However, the process is mediated by a large number of social and environmental factors leading to outcomes that differ locally.

Land degradation as a symptom of loss of resilience is a phenomenon of widespread occurrence in grazing lands (Detsis 2010). Similar problems are reported in other areas of the Mediterranean and Africa, such as Syria (Louhaichi and Tastad 2010), Algeria (Slimani et al. 2010), Ethiopia (Tschopp et al. 2010), and Morocco (le Polain de Waroux and Lambin 2012), and other areas of Greece (Kizos et al. 2013). These case studies offer a wide range of differing causal connections between grazing and land degradation, as well as a range of modes of interweaving between effects of grazing and other local or higher scale proximal causes of degradation. The common thread is the understanding that causes like attitude toward rangeland resources, (un)willingness of parties to cooperate, and the local knowledge base available play a major role. Although not explicitly treated as such by these authors, such aspects fall into the concept of "social capital."
In general, the SER of a system results from the interactions among several forms of capital (Adger 2003, Resilience Alliance 2007). Social capital influences land management and SER both positively and negatively (Aldridge and Halpern 1998). Bridging social capital is often associated with more sustainable land management practices because it may enhance trust and cooperation among different social groups (see Burgess et al. 2000, Tuvendal and Elmqvist 2011). Swinton (2000:1) reported that "more social capital" leads to "less soil erosion," because the formation of networks between local producers had positive impacts on mitigating soil erosion, land degradation, and desertification in Peru. Although "action by one farmer to reduce water or wind erosion may benefit neighboring fields ... these benefits are not fully captured by the farmer making the conservation investment," but "when economic actors care for one another, these externalities can be internalized, reducing the individual's disincentive to perform a socially level of natural resource conservation" (Swinton 2000:1). Karametou and Apostolopoulos (2010) found similar associations in their research in mountainous communities in Epirus, Thessaly, and Magnesia, Greece. "Weak" bridging social capital and "strong" bonding social capital had negative impacts on land quality mainly because this combination favors the formation of exclusive social groups, promotes social antagonism and conflicts, and mitigates the prospects for broader cooperation toward sustainable land practices. Daud (2006) demonstrated the positive consequences that the formation of bridging social capital has for water use in an area of increased irrigation needs in Indonesia. The manifestations of the link between social capital and SER in the Asteroussia area are our focus as detailed subsequently.

\section{RESEARCH APPROACH}

\section{Conceptual framework}

We have based our study on the notion that societies and the natural environment in which they are embedded can be understood as an integrated SES. Such systems may shift between different states. Within each state of an SES, different factors from varying spatial and temporal levels interact. Some of them act on lower spatial levels and within shorter time frames than the processes defining the system identity, whereas others exceed to a lesser or a greater extent the spatial boundaries or the duration of a particular state (Dearing et al. 2010, Folke et al. 2010). At the same time, some of these factors are subject to control and manipulation by local actors, whereas others are not.

Self-organization in complex SESs is different from that in pure natural systems (Westley et al. 2002) because humans have the unique capacity for foresight and deliberate action. However, it can be argued that although the dynamics and direction of change in such systems are influenced by individuals and groups that have intent, the system as a whole does not. The capacity to actually manage resilience with intent determines whether social groups can successfully avoid a system shift into an undesirable regime or succeed in shifting it into a desirable one. In this sense, social capital mediates the relationships of economic and environmental systems to steer the evolution of an SES within the boundaries set by the latter.

By adopting an evolutionary approach and studying the mechanisms of the emergence of its various characteristics (Dearing et al. 2010), the Asteroussia Mountains system trajectory was followed from approximately 1950 to the present 
day. The evolution of the SES of the Asteroussia Mountains is outlined by describing its main properties as well as the types of land use and social relationships that shape its identity. The present is treated as a point in a long continuum. The trajectory of the SES is followed through its shifts; transition phases are detailed to highlight the driving forces that caused them. The identities of the different states are described to sort out fast and slow processes and the legacies carried along from the past throughout the trajectory. The main focus was on the interweaving of processes operating at different timescales and the effects they produce with regard to the system stabilization by negative feedback or the triggering of system transitions by positive ones (Kinzig et al. 2006).

Prominent among these processes was the evolution of the type, character, and properties of social capital and its interactions with other political, economic, and socio-cultural factors (see also Cosyns et al., in press, Fisher 2013). The role that it played through time in shaping the identities of the different states of the SES is highlighted, with a special focus on the generation of crucial feedback mechanisms. By explicitly taking into account normative aspects, change or lack of change is not treated as such but with respect to the role it plays in the preservation of natural resources and the social relationships emerging from it.

\section{Research methodology}

A qualitative approach was adopted to investigate how changes within and between different types of social capital affect the SER of an SES, by focusing on processes that connect people and social groups to each other and how these relate to the natural environment and utilization of its resources. A number of in-depth interviews with carefully selected key stakeholders in the study area were carried out. This decision was guided by the need to understand changes of social capital, from one type to another, and transformations within each type.

The in-depth interviews with local stakeholders were conducted in 2 rounds. The first round of 20 interviews was carried out in November 2011. Another round of 14 interviews was carried out in the summer of 2012 to verify the findings of the first round. In the first round, the following interviews were conducted: regional authorities (1); local municipalities (4); local geotechnical chamber (1); local development company in charge of managing the European Union (EU) Leader policy initiative for rural innovation in the wider Heraklion area (1); local environmental NGOs (2); livestock farmers (5); olive farmers (3), typically also from local cooperatives; a private adviser for livestock farmers (1); and agrifood manufacturers (2), i.e., one small cheese maker and a producers' group of organic vegetables. In the second round, the interviews were with community council people (3), a municipal council member (1), local businessmen (2), women farmers (2), expresidents of community councils (2), livestock farmers (2), a vine farmer (1), and an olive farmer (1). The selection of regional authorities, the local geotechnical chamber, and the local development company was guided by the need to have the views of stakeholders with a broader perspective than residents of the area, but who were all well acquainted with the area and its issues. All interviews were tape-recorded with the informed consent of research participants and subsequently transformed into text, paying special attention to the accuracy of the transcription process.

The selection of respondents was guided by the need to cover as many different types of local stakeholders as possible and to collect information on past practices, especially from members of local municipality boards. The interviews were based on a flexible guide, and the respondents were encouraged to discuss freely the themes and expand on them during the interview process. The duration of interviews varied from half an hour to more than three hours, and they were conducted using a comprehensive interview guide, which concerned conceptualizations of land degradation and desertification problems in the area, land management practices, social and institutional relations and conflicts, formal and informal networks of cooperation or competition, along with the characteristics and dynamics of the local economic, socio-cultural, and political context. We opted for a thematic analysis of the collected qualitative data, that is, an analysis of the participants' responses to thematic areas already included in the interview guide and to thematic areas that emerged during the research process. Qualitative data analysis was conducted through a process of detailed segmentation of interview material according to preconceived and emerged themes, determination of the meaning of each theme, and linking between different themes. The latter involved the connection of the participants' perspectives as regards each theme to their actual practices and to the social relations, from the micro- to macrolevel within which the participants were embedded.

The timescales required to investigate changes of social capital are often very long, whereas respondents tend to focus on more recent experiences and speak with current events in mind. Therefore, secondary data supplemented the primary interview data collected. Secondary data came from the 1961, 1971, 1991, and 2000 censuses of agriculture and animal husbandry and the 1961, 1971, 1981, 1991, 2001, and 2011 population censuses (ESYE 1962, 1964a, 1964b, 1972a, 1972b, 1979, 1991, 1994, 1995, 1998, 2003, 2004). Data from the Common Agricultural Policy (CAP) subsidy to farmers, the Single Farm Payment (SFP), database were also used. Data from other published and unpublished sources were also utilized (Kloutsinioti 1998, Liodakis 2000).

\section{Social capital and SER in the Asteroussia Mountains}

\section{The Asteroussia Mountains SES}

The Asteroussia Mountains study area is a typical semiarid hilly/ mountainous area of the eastern Mediterranean in which land degradation is one of the most important land management issues. The study area has supported large populations of grazing animals for many centuries by relying on mixed systems of cultivation and grazing, linked via transhumance practices with the neighboring Messara plain. Recently, the intensification of grazing and the separation between animal husbandry and crop cultivation has challenged and transformed these links with important negative impacts on vegetation and soil. The size of the flocks has increased significantly during recent decades (Table $1)$.

Geographically, the Asteroussia Mountains are located in the south of the Heraklion Prefectural Unit of Crete, below the Messara plain (Fig. 1). They stretch over $387 \mathrm{~km}^{2}$; they include 14 settlements and have a population of 6869 residents (ESYE 2004). The highest peak is at $1231 \mathrm{~m}$. The climate is typical Mediterranean. Low-elevation areas receive $500-750 \mathrm{~mm}$ of rainfall annually, average air temperature is $21^{\circ} \mathrm{C}$, and rainfall increases and temperature decreases with altitude (Land \& Ecosystem Degradation \& Desertification Response Assessment 
Table 1. Socioeconomic indicators for Crete, Heraklion, and Asterousia Mountains areas, 1961-2011.

\begin{tabular}{|c|c|c|c|}
\hline Indicator & Crete & Heraklion & Asteroussia \\
\hline Population change $(\%)$ 1961-2011 & 41.3 & 62.2 & -30 \\
\hline Population aging 2001 (1991) & $95.9(70.7)$ & $88.4(58.2)$ & $160.6(107.9)$ \\
\hline $\begin{array}{l}\text { Persons occupied in primary production \% of total occupied } 2001 \\
(1991)(\%)\end{array}$ & $23.9(32.1)$ & $23.2(31.2)$ & $62.3(70.5)$ \\
\hline GDP per capita \% of national average 2009 (1981) & $89.7(79.1)$ & $100.6(83.3)$ & - \\
\hline Farms change $1961-2000(\%)$ & -10.1 & -2.2 & -23.7 \\
\hline Average farm size 2000 (1961) (ha) & $4.2(4.6)$ & $3.3(4.1)$ & $8.0(7.7)$ \\
\hline Farm land change $1961-2000(\%)$ & -28.4 & -24.5 & -43.1 \\
\hline Farms with $\mathrm{UAA}^{\dagger} 2000$ & $93,895.0$ & $42,507.0$ & $1,810.0$ \\
\hline UAA change $1961-2000(\%)$ & -17.5 & -20.9 & -20.2 \\
\hline Grazing land $\%$ of UAA 2000 & 45.5 & 25.9 & 61.0 \\
\hline Grazing lands change $1961-2000(\%)$ & 0.9 & -8.8 & 7.2 \\
\hline Sheep per farm 2000 (1961) & $92.4(9.2)$ & $85.5(6.8)$ & $94.9(13.6)$ \\
\hline Goat per farm 2000 (1961) & $29.6(4.3)$ & $24.4(2.9)$ & $42.7(6.3)$ \\
\hline Sheep and goats change $1961-1971(\%)$ & 36.0 & 45.3 & 63.7 \\
\hline Sheep and goats change $1971-1991(\%)$ & 87.2 & 62.2 & 54.4 \\
\hline Sheep and goats change $1991-2000(\%)$ & 29.3 & 45.4 & 14.9 \\
\hline Sheep and goats change $1961-2000(\%)$ & 229.3 & 242.6 & 190.5 \\
\hline Sheep farms (\%) of farms 2000 (1961) & $17.3(41.2)$ & $10.5(31.5)$ & $34.1(66.9)$ \\
\hline
\end{tabular}

Sources: ESYE 1964a, 1979, 1998, 2003, processed by the authors

${ }^{\dagger}$ UAA: Utilized agricultural area; includes the land categories: arable land; permanent grassland; permanent crops.

[LEDDRA], unpublished manuscript). The geologic substrate consists of flysch and limestone. Most of the area is covered by shallow to very shallow soils. Slopes are generally steep, with slopes of $35-60 \%$ gradient covering almost $50 \%$ of the total area. The combination of climate, geology, soils, and high slope gradient makes the area relatively unfavorable for plant growth and highly susceptible to water erosion, especially under low vegetative cover in flysch areas. Therefore, the impacts of overgrazing can be severe, leading to high rates of soil erosion; $80.8 \%$ of the total area of Asteroussia is included in the EU's Natura 2000 network.

Land cover is characterized as grazing lands, $61 \%$ of the total area according to the official land cover data of 2000, of typical Mediterranean phrygana vegetation. In the past, arable crops were encountered, but they declined rapidly in the 1970 s and 1980 s, $-90 \%$ from 1961 to 2000 according to official censuses, and were replaced by olive plantations in the lowland areas and by grazing lands in the mountains (ESYE 1962, 1979, 1995, 1998, 2003).

The evolution of the Asteroussia Mountains SES since the 1950s The Asteroussia Mountains SES has undergone a number of important economic and social changes that have modified its SER. For the purposes of the present analysis, two different periods have been identified that characterize the evolution of the SES since the 1950s and correspond to two different states of the system. These states reflect periods of greater socioeconomic, institutional, and political changes in the wider region, Greece, Europe, and the rest of the world. The first of these states, the "semiarid husbandry" state, extends roughly up to the end of the late 1970 s to early 1980 s, when the system undergoes a relatively brief transition lasting up to the mid- to late 1980s, when a new state is established, the "subsidized husbandry" state, which is terminated around 2008 because of the ongoing economic crisis.

Roughly up to the 1970s, the area had a subsistence economy that depended very heavily on the primary sector. The available statistical data reveal that as late as 1971 agriculture provided employment to more than $70 \%$ of the active population of Asteroussia. In the 1970s, the emergence of tourism in other parts of Crete and the enhanced importance of the city of Heraklion regionally accelerated economic growth and created new jobs. Some jobs were created in Asteroussia, and according to our respondents, ready cash became available from remittances of migrants in Heraklion, Athens, or abroad. The availability of cash is one of the limiting factors in this particular state. The 1980s marked a rapid growth of the regional economy; gross domestic product (GDP) per capita for the Heraklion Prefecture, for which data is available, rose from $83.3 \%$ of the national average in 1981 to $90.7 \%$ in $1991,105.7 \%$ in 1994 , and $100.6 \%$ in 2009 (Table 1 ). The share of the primary sector decreased regionally, but in Asteroussia, the primary sector still provided almost all of the jobs, $70.5 \%$ in 1991 and $62.3 \%$ in 2001 , because jobs in other sectors were few, mostly in the construction sector and the public sector.

According to the census data, the number of farms has decreased by $24 \%$ from 1961 to 2000 (all data processed from censuses ESYE 1962, 1979, 1995, 1998, 2003). The highest decrease was recorded from 1971 to 1991 . However, the average size of farms increased only slightly from 7.7 ha per farm in 1961 to 8.0 ha per farm in 2000 (Table 1). This is the result of a significant decrease of cultivated land, $-43.1 \%$ in 40 years, and the increase of grazing 
Fig. 1. Physical and administrative limits of Asteroussia Mountains.

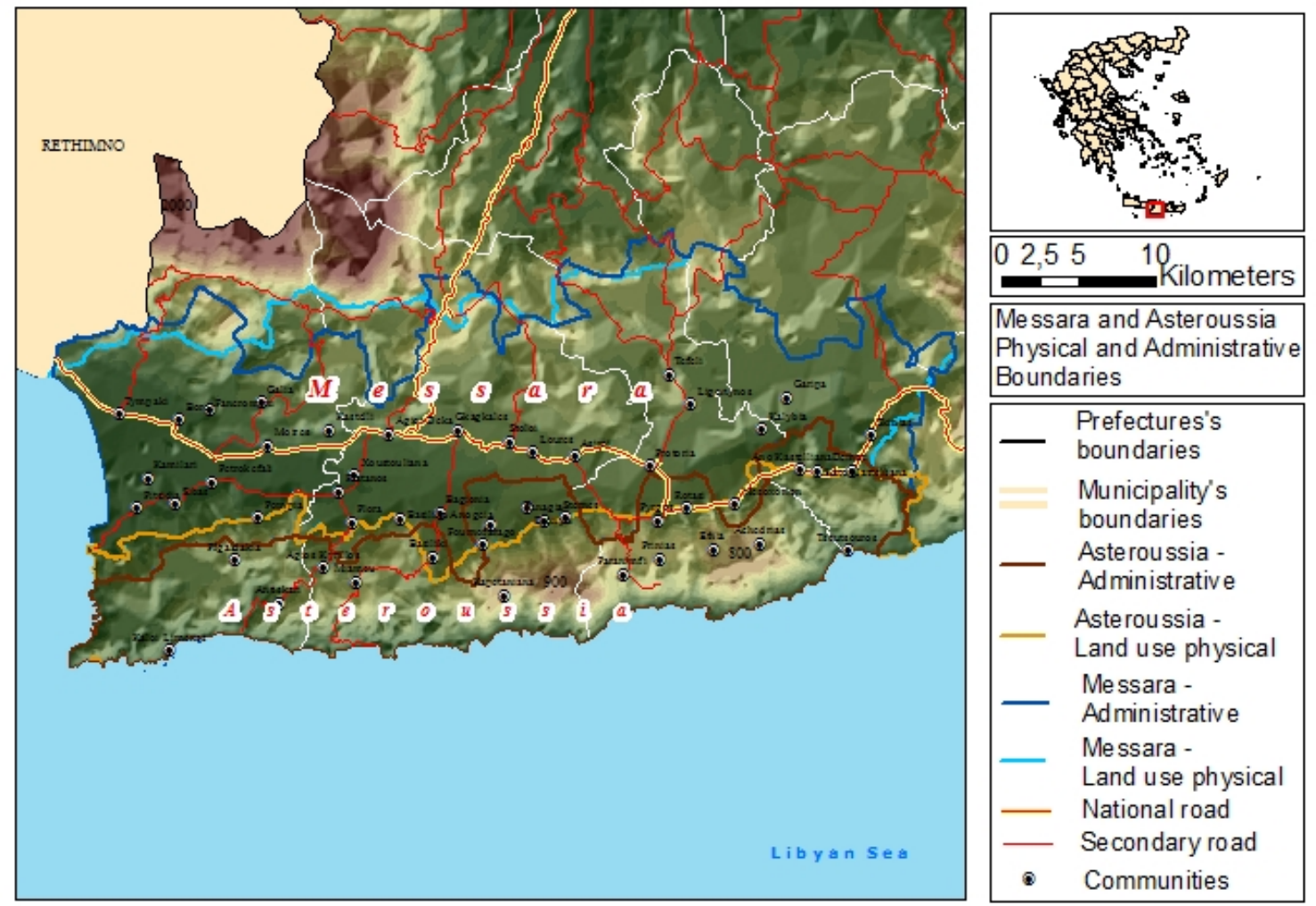

lands during the same period that in 2000 covered $61 \%$ of the total Utilized Agricultural Area, 144,855 ha. The number of animals, mostly sheep and goats, has increased during the past 40 years by $190.5 \%$, leading to the intensification of grazing and the "professionalization" of sheep farmers, as the number of sheep and goats per farm rose from 13.6 and 6.3, respectively, in 1961 to 94.9 and 42.7, respectively, in 2000 (Table 1). The highest increase (63.7\%) was recorded between 1961 and 1971, when commercial feed became gradually available, according to our informants. Animal husbandry infrastructure, including stables, storehouses, milking pens, and enclosure walls or fences, is very important for farms and land management in the area.

The commencement of the CAP regime in Greece, which provided subsidies to farmers, marks the beginning of the transition period in the mid-1980s. Unlike other areas in Greece, the implementation of the CAP in the Asteroussia Mountains did not result in a change in land cover, because of the physical characteristics of the area. It only accelerated the pre-existing tendency to increase flock size. In the 1980s and 1990s, the payments were made according to the magnitude of production, with national caps for different products established since the early 1990s. The rationale of national, regional, and local authorities was "to avoid 'losing' money" that could be paid to the local farmers. Informal networks were set up that provided services to ensure access to and eligibility of the beneficiaries for the subsidies provided. As a result, respondents asserted that large amounts of ready cash became available, which was spent mostly on purchasing urban dwellings and other amenities. Part of the cash was invested in agricultural technology and machinery, especially because many of these investments were subsidized by the CAP through the so-called Structural Pillar as well. The SFP was introduced after 2005, and its 2009 files recorded 2410 beneficiaries, 58 years of age on average, i.e., $37 \%$ older than 65 and $15 \%$ younger than 40 , each receiving $€ 3099$ on average, i.e., $32 \%$ receiving less than $€ 1000$ and $5 \%$ more than $€ 10,000$ annually.

Social infrastructures were limited in the area before the 1980s, as in other rural parts of Greece at the time. Students attended school in the larger villages in the Messara valley, which forced many high school students to drop out early. Today, things have significantly improved, but issues of transport remain important. Similarly, health care was provided in Messara, which has not changed today. The geographic remoteness of the area and the distance from the main transport nodes of the region, i.e., Heraklion port and airport, together with the low quality of local transport infrastructure owing to the rough terrain, result in linking many geographically proximate settlements only via long detours through the plain of Messara and add to the disadvantages that the residents have to face.

Today, the multifaceted crisis is transforming the system characteristics evolved in the "subsidized husbandry" state and the associated practices in more than one way. Although the extent of the local recession is not known, the national average is $-15 \%$ 
of GDP between 2008 and 2011, and continued recession is forecast for 2012-2013. Besides the impacts of this prolonged recession on jobs and production, one of the lesser known aspects has been the scarcity of credit and cash, which is today a limiting factor for the SER of the system.

The evolution of social capital in the Asteroussia Mountains SES since the $1950 \mathrm{~s}$

Asteroussia suffered a population decline, like many other similar mountainous and/or remote areas in Greece, after the 1960s, i. e., $-30 \%$ from 1961 to 2011 (Table 1). The remaining population has aged, with the aging indicator at 160.6 compared to 84.4 in Heraklion. Besides aging, the education level is also low, with $69 \%$ of the population being primary school or lower graduates. These developments seem to mirror the ongoing economic and social marginalization of the area.

The cultural capital in Asteroussia, as in many rural and mountainous areas of Crete dependent on livestock husbandry (Tsantiropoulos 2010), is characterized by peculiarities that affect social relations and the relations of primary producers to land, natural resources, and the environment. The interviews revealed that social organization is based on extended family and kinship networks. Moreover, animals are not just an economic asset that is the object of "rational management." They also have symbolic meaning as a status symbol, which plays a major role in their management. Stockbreeders, according to our respondents, are emotionally attached to animals and to open space that is identified with a sense of "freedom"; they are called kapetanioi, meaning leaders, captains in Crete, to signify their status and role in society. This sense plays an important role in their almost intuitive resistance to attempts at "modernization" of primary production, decrease of animal numbers, and so forth. The sociocultural value and status of the extended family and kinship group is partly dependent on the magnitude of the herd and, because men manage the farms and the animals, on the number of sons, as well as on the size of the kinship group (Tsantiropoulos 2010). Status competition and conflict among kinship groups sometimes takes on extreme forms of violent conflict, criminality, and avoidance of any social relation with other opposing families and kinship groups (Tsantiropoulos 2010). It is relatively easy to understand that this type of social organization erodes the prospects for developing wider social trust among different groups and severely limits the chances of engagement in common, collective activities and practices. The following quote from our interviews highlights this situation:

My two grandfathers were big stockbreeders in my village. The one had 2500 sheep and the other 100 more. The one was trying to surpass the other. The one had 5 sons, the other 4. [...] They used to share the mountain behind me [...] my father fell in love with my mother [from the other family] and got married. In this way the conflict stopped because otherwise we would have victims.... And I say to you, all these create a pattern of behavior as regards the actions of the stockbreeder. How he sets boundaries in space in order to have his own space, that he has to have the largest herd, that he has to have many male members in the family, that he has to come from big "soi" [kin, extended family]. (Interview with a representative of a municipality in the area, July 2012)
These family-kinship networks are a form of extremely strong bonding social capital. After the 1980s, our informants assert that this capital was strongly articulated with new ways of making money, such as the subsidy regime and production of market goods. This form of social organization is accompanied by strong personal connections and linkages based on common places of descent (see also Tsantiropoulos 2010). Individuals from the same village or area also form marital and kinship relations with each other to reinforce links, and these practices form identities and set boundaries with other groups. Bigger herds and larger families also made more powerful groups politically and socially, and this was commented on by both sheepherders and the rest of the actors in the area.

This situation and the widespread social distrust intensified and was reinforced after the introduction of agricultural subsidies in the 1980s. The way that subsidies were allocated, i.e., mostly through clientelist networks according to our respondents, led to their appropriation as an additional source of income and as a means for making "fast" and "easy" profit. Subsidies in the 1980s and 1990s were linked to the number of animals and not to regulations for modernization of production and environmental sustainability. Combined with the already large increase in the number of animals in the previous decade, this led to an excessive increase of the animal capital in the area (Table 1) and to serious problems related to pressures on land and other natural resources, mainly because of overgrazing, as many of our respondents assert.

At the present time, livestock farmers report that "the sheep are starving." The deadlock for them is apparent because the overgrazed and insufficient grazing lands cannot replace imported feed that the farmers are nowadays unable to purchase because of the current lack of cash and credit. Moreover, and as several of our interviewees reported, the unequal allocation of subsidies through clientelist networks in the area has further eroded social trust and trust in institutions.

The level of wider social trust is very low not only among stockbreeders in Asteroussia but also between them and the farmers in Messara, as both parties assert. Problematic relations between livestock breeders and farmers are commonly encountered throughout Greece for similar reasons; one of the eyewitnesses of the last transhumance trips of herders in central Greece, Salmon (1995), reports many such incidents. Although seasonal transhumance was widespread in Messara in the past and allowed higher grazing densities, today stockbreeders and farmers view each other antagonistically. Several of our research participants referred to incidents that show that the purpose of each group is to appropriate the resources of the other without any consideration of possible harm. The availability of cash and easy credit in the 1980s and 1990s along with subsidies allowed the separation of the mountains from the plain with the use of imported animal feed and the growth of the number of sheep and goats until the economic crisis made imported feed too expensive for stockbreeders. The following quotes highlight issues of lack of trust among stockbreeders and between stockbreeders and farmers:

You can work with stockbreeders' culture but in another level. You cannot bring them to the same table because they will kill each other. (Interview with the 
representative of the development company in Heraklion, November 2011)

The mentality has not gone. The war over grazing land has never stopped [...]. The one stockbreeder tries to steal, to do harm to the other, it is a local mentality. This is why stockbreeders form many kinship connections, marriages with each other, even now. Those in Psiloritis ask for help from those from Chania, they form kinship connections with others from Sfakia, etc. There is a kind of masonry in stockbreeders here. (Interview with the representative of an environmental NGO in Heraklion, November 2011)

The area has undergone two administrative restructurings, the first in 1997 and the second in 2010, which merged smaller administrative units into larger municipalities. The second restructuring established elected regional authorities with significant responsibilities in policy making and planning for the first time. However, both the previous and the current administrative subdivisions do not follow the physical geography of the area. A smaller or larger part of most of the upland settlements of Asteroussia belongs to the lowland areas of the Messara plain. The recent restructuring formed new administrative boundaries that do not correspond to local sentiments; residents of Asteroussia feel that the power balance has turned to the more populous settlements of the plain, whereas residents from the plain complain that the power balance is tipped by "powerful stockbreeders" toward the mountains. So far, the local opinion is that new forms of local administration are not really a change from the previous top-down status. Therefore, trust toward regional and local institutions is still extremely limited. Some characteristic quotes from interviews with two stockbreeders in Asteroussia are telling:

There is no comprehensive planning either from the state or the regional authorities of the municipalities. The basic purpose of the political leadership all these last years and from the lower administrative agencies and the cooperatives was the promotion of clientelist relations. Those clientelist relations have reduced the values in the area that is, how we behave to each other and how we behave towards the natural resources and the environment. (Interview with a stockbreeder in Asteroussia, November 2011)

The state has to give the capacity to local institutions, such as the new regional authority, give power to the lower ranks of local government so that they have the capacity to shape better conditions for the inhabitants. (Interview with a stockbreeder in Asteroussia, November 2011)

Today, stockbreeders face an economic deadlock. On one hand, expenses and especially the price of feed have increased disproportionately compared to the price of milk, which is their main commodity; the price index of animal fodder increased $13.8 \%$ in $1995-2000,17.3 \%$ in $2000-2005$, and $42.7 \%$ in $2005-2011$ compared to $3.2 \%, 18.8 \%$, and $5.2 \%$ for the ewe milk index, respectively. On the other hand, subsidies are lower and controls stricter, cash and credit are harder to find, and even seemingly strong previous networks collapse. As the head of the stockbreeders of Heraklion described it:
Each of us had his milkman, his cheese maker and his butcher. When he wanted money he went to them and got some. He had the feed provider and got credit for his feed. He had solutions to everything... now you can't even find a bag of feed for the animals. This is gone now. Social relations with the rest of the professionals, who they made koumparous [best men, a form of kinship considered very important in Crete] and sinteknous [fellows, i.e., relatives, another form of friendship network considered very important in Crete] to have their guys. Now there is nothing. (Interview, November 2011)

These kind of practices are no longer available, and although many recognize that collective management and action could provide some solutions, the erosion of trust and bonding networks between them does not make discussions easy. A young farmer justified his decision to be involved in the local cooperative as follows: "It is difficult [to work together] and I got in [as president in the local and dysfunctional cooperative] because no one else wanted to" (Interview, November 2011).

\section{DISCUSSION: THE INFLUENCE OF CHANGES IN SOCIAL CAPITAL ON THE SER OF THE ASTEROUSSIA MOUNTAINS SES}

Grazing lands in Crete and in other areas of the Mediterranean and North Africa with similar soil and climatic conditions have generally been reported to suffer from land degradation in recent decades (Hostert et al. 2003). The assumed link between animal numbers, overgrazing, and land degradation was acknowledged by our respondents, including the stockbreeders. Our findings seem to confirm the suggestion that production has become increasingly decoupled from land productivity (Lorent et al. 2009), although intensive use of fodder was found to be associated with poor economic performance.

The gradual but steady erosion of bridging social capital after the 1980s has contributed to the growing land degradation problems in the area. This state seemed to be very resilient economically and socially for many actors of the area, though not equally and not for all, but less so environmentally. This finding is supported by the literature because bridging social capital is associated with the enhancement of trust and cooperation among different social groups (e.g., Daud 2006, Karametou and Apostolopoulos 2010, Ohno et al. 2010). In Asteroussia, the formation of horizontal networks by local producers today is problematic, and the differences between the states of the SES of Asteroussia are important: Before the 1980s, bridging social capital coshaped relations and practices of farmers, in the form of wider networks between stockbreeders and the farmers of Messara. Without implying that this kind of capital made the SES more resilient, it nevertheless is related with long-term concern for land quality (see also Ruben and Heras 2012, Hoogesteger 2013). Even the concerns for sons, who cover the necessary labor needs and provide long-term prospects for the farm, can be considered as a long-term land management concern. This capital slowly but steadily eroded during the 1980s, and this contributed, along with other factors such as the availability of cash, hired labor, and imported feed, to the growing land degradation problems in the area. "Closed" social networks are found in both states, either family or patron-client networks, but their content and purpose changes as bonding and clientelist networks become strongly 
articulated with the allocation of agricultural subsidies. Generally, the evolution of social capital in the Asteroussia area, despite socioeconomic and political changes, shows the long-term inability to form wider bridging and linking kinds of social capital and networking either within the area and among stockbreeders or between Asteroussia and other neighboring areas, such as, for example, the farming area of Messara. Linking social capital did not emerge from the responses or the secondary material available as an important component in the processes we have discussed. On the contrary, the lack of bridging social capital was recently reported to hamper the development of the social learning process necessary to adapt to the current conditions or to transform the SES (Pahl-Wostl et al. 2007). These changes have to be viewed together with a number of wider economic and social developments that have contributed to the shift of SER of the SES.

One of the most important factors for this loss of bridging social capital after the 1980s was the introduction of CAP subsidies. Our findings indicate that the articulation between social capital and agricultural subsidies is strongly related with the nature of social relations in the area. Initially, in the 1980s, subsidies were allocated through informal patron-client networks, which undermined the prospects for the modernization of production and environmental sustainability. Under this regime, subsidies were mainly seen as additional and "easy" income. They exacerbated economic and social inequalities in the area and further eroded trust between individuals and social groups and between social groups and formal local/regional institutions (Paraskevopoulos 2007). Moreover, this way of allocating agricultural subsidies undermined past social relations of trust, solidarity, and reciprocity among farmers, including sheepherders, in the area (see also Cosyns et al., in press, Fisher 2013). This also led to the neglect of the quality and long-term conservation of the land and to investments in the intensification of land-use practices mainly because primary producers would not connect their income to the long-term quality of land.

Another important factor is related to external inputs and cash availability. The "semiarid husbandry" period was characterized by the lack of external inputs for production, and therefore stockbreeders had to find ways to cooperate with farmers in Messara for the necessary extra feed that the area could not provide. Because cash and credit were also not available, hired labor was not an option, and families had to provide all required labor. The availability of cash and credit, as well as subsidies, in the transition period changed all these realities very quickly. First, feed and then hired labor became integral parts of management systems and allowed bigger herds. Then, subsidies became integral parts of farming incomes, and farmers felt as if they were "entitled" to money despite their farms and practices (Papadopoulos 1999). The rapidity with which the system adopted these practices can be partly attributed to the fact that through the linkage of subsidies to flock size the system was compatible with the frame set by the prevailing culture of the area (Pahl-Wostl et al. 2007, Scheffer and Westley 2007, Pahl-Wostl 2009). The most serious negative impact of all these changes has probably been the abandonment of longterm care of the land. Primary producers have ceased to associate their income with land quality, and this is one important reason, among others, for the intensification of grazing densities and the abandonment of practices that considered vegetation and soil quality.
Trust, considered in the literature as one the most important features upon which social capital is built (Cosyns et al., in press, Ruben and Heras 2012, Hoogesteger 2013; see especially Fisher 2013), toward other local/regional-level collective action institutions is also limited. The strong bonding social capital based on family and kinship networks plays an important part here as well, especially when such networks crosscut with patronclient relations between stockbreeders and institutional representatives. This reinforces the general distrust among them regarding the intentions and rhetoric of institutional bodies. Under these conditions, projects for "rationalization" or "modernization" of stockbreeding production or attempts to introduce viable policies, such as the extensification of grazing carried out under the CAP in the early 2000s, face serious resistance.

Another important finding concerns the temporal scales on which some of the driving forces act and interact. Some of these are very short term and completely out of the control of local actors, e.g., economic conditions, with the recent economic crisis in Greece a telling example. Others concern the medium term, agricultural subsidies being the most important in our case, from the mid-1980s until today. Finally, there are some that derive from very long-term processes, compared to human life duration, and are difficult to change; however, once they do change, they have immensely important effects on land management practices, effectively "pushing" the SES toward another state. Such longterm characteristics in the case of Asteroussia are trust networks and social capital characteristics in general.

The timescales required to investigate changes in social capital were longer than the shorter term focus of most of the respondent, who tended to speak with current events in mind. Our findings stress the importance of social capital, in the Asteroussia case especially social trust among individuals, social groups, or institutions, and call for new approaches that can incorporate different timescales and social processes into resilience thinking.

\section{CONCLUSIONS}

The research approach we followed sought to explore some of the interactions between social, economic, and environmental factors qualitatively. The focus was on the impacts of changes in longterm characteristics of an SES on land degradation problems in a particular geographic, policy, social, and economic context. Without underestimating the importance of quantitative data, the qualitative interviews, and their interpretations by the research group, provide some of the keys for understanding these changes and highlight some important aspects.

Land degradation problems are social-ecological problems, and the understanding and analysis of the processes that affect them is of great importance. At the same time, these processes are complex and interact with natural and economic driving forces less apparently related to land management. We found that different types and changes of social capital influenced the SER of a region. Changes of the same type of social capital, i.e., bonding capital, are partly responsible for the economic and environmental problems the study area faces. Despite the many economic and social changes of the broader area and the different types of bonds, i.e., over kinship, political networks, and subsidies, this type of bonding in small antagonistic groups has made the actors of the area unable to overcome personal strife and conflicts 
and manage the land more effectively in the long term and without external inputs, such as feed or subsidies. The difference with the "semiarid husbandry state" lies in the utilization of external production inputs: When these were not available or affordable, actors had to work together and place some trust in other networks. It remains to be seen if the ongoing unavailability of such external inputs today will have the same effects in the future. Until recently, strong peer control has been exerted, and the various groups have applied the same practices leading to lack of diversity that would nurture innovation. The problem is exacerbated because the current system has proved efficient in the recent past, in economic terms at least. On top of this, vested interests of the existing power structures are served well by the present organization. All these make response to altered external conditions difficult and delayed (Scheffer and Westley 2007). Therefore, the relevance of exploring the question "resilience of what and for whom?" is underlined for resilience thinking.

More generally, the findings suggest that the articulation of persistent, slow variables, such as cultural factors, with newly appearing, faster ones, like subsidy regimes, in a low-productivity natural environment led to a change in the state of the system. In turn, the stabilization of the "subsidy state" fed back on the slow variable by strengthening bonding social capital and giving it a new character through its interweaving with clientelist networks, while at the same time weakening the bridging one. These changes resulted in the erosion of the collective ability of social actors to cope with the current crisis, locally manifested by the inability to buy inputs, combined with the capacity lost, during the "subsidy state," to internally or regionally cover production needs by forage production. The system presently seems to be locked in a trap with a forced transition pending or already under way.

Responses to this article can be read online at: http://www.ecologyandsociety.org/issues/responses. php/6208

\section{Acknowledgments:}

The research was financed by the European Union project LEDDRA (FP7-ENV-2009-1 Collaborative Project, No. 243857; 2010-2014). We would like to acknowledge the assistance of H. Briassoulis and her critical reading of earlier versions of the manuscript. We also acknowledge the assistance of $K$. Kosmas for the provision of meteorologic, geologic, geomorphology, and land cover data.

\section{LITERATURE CITED}

Adger, W. N. 2003. Social capital, collective action, and adaptation to climate change. Economic Geography 79:387-404. http://dx.doi.org/10.1111/j.1944-8287.2003.tb00220.x

Aldridge, S., and D. Halpern. 1998. Social capital: a discussion paper. Performance and Innovation Unit, Cabinet Office, London, UK.

Burgess, J., J. Clark, and C. M. Harrison. 2000. Knowledges in action: an actor network analysis of a wetland agri-environment scheme. Ecological Economics 35:119-132. http://dx.doi. org/10.1016/S0921-8009(00)00172-5
Cosyns, H., P. Van Damme, R. De Wulf, and A. Degrande. In press. Can rural development projects generate social capital? A case study of Ricinodendron heudelotii kernel marketing in Cameroon. Small-scale Forestry. http://dx.doi.org/10.1007/ $\underline{\text { s11842-013-9247-1 }}$

Cote, M., and A. J. Nightingale. 2012. Resilience thinking meets social theory: situating social change in socio-ecological systems (SES) research. Progress in Human Geography 36:475-489. http:// dx.doi.org/10.1177/0309132511425708

Crane, T. A. 2010. Of models and meanings: cultural resilience in social-ecological systems. Ecology and Society 15(4): 19. [online] URL: http://www.ecologyandsociety.org/vol15/iss4/ art19/

Daud, S. B. 2006. Community empowerment and irrigation management: a case of water users association in south Sulawesi, Indonesia. Pages 41-66 in S. Yokoyama and T. Sakurai, editors. Potential of Social Capital for Community Development. Report of the APO Survey and Symposium on Redesigning Integrated Community Development 2003-2005, Asian Productivity Organization, Tokyo, Japan. [online] URL: http://www.apotokyo.org/publications/files/agr-17-psc.pdf

Davidson, D. J. 2010. The applicability of the concept of resilience to social systems: some sources of optimism and nagging doubts. Society \& Natural Resources 23:1135-1149. http://dx.doi. org/10.1080/08941921003652940

Dearing, J. A., A. K. Braimoh, A. Reenberg, B. L. Turner, and S. van der Leeuw. 2010. Complex land systems: the need for long time perspectives to assess their future. Ecology and Society 15 (4): 21. [online] URL: http://www.ecologyandsociety.org/vol15/ iss $4 / \operatorname{art} 21 /$

Detsis, V. 2010. Placing land degradation and biological diversity decline in a unified framework: methodological and conceptual issues in the case of the north Mediterranean region. Land Degradation \& Development 21(5):413-422. http://dx.doi. org/10.1002/ldr.980

Ethniki Statistiki Ypiresia Elladas [National Statistical Service of Greece](ESYE). 1962. Katanomi ektaseos tis Ellados kata vasikes katigories hriseos (Proapografika stoiheia apografis georgiasktinotrofias tou etous 1961) [Distribution of the country's area by main categories of land use (Precensus data of agriculturelivestock census of 1961)]. ESYE, Athens, Greece.

Ethniki Statistiki Ypiresia Elladas [National Statistical Service of Greece] (ESYE). 1964a. Apotelesmata tis apografis georgiasktinotrofias tis 19 Martiou 1961 [Results of agriculture-livestock census of 19th March 1961]. ESYE, Athens, Greece.

Ethniki Statistiki Ypiresia Elladas [National Statistical Service of Greece] (ESYE). 1964b. Apotelesmata tis apografis plithismoukatoikion tis 19 Martiou 1961 [The population-housing census results of 19th March 1961]. ESYE, Athens, Greece.

Ethniki Statistiki Ypiresia Elladas [National Statistical Service of Greece] (ESYE). 1972a. Apotelesmata tis apografis plithismoukatoikion tis 14 Martiou 1971 [The population-housing census results of 14th March 1971]. ESYE, Athens, Greece.

Ethniki Statistiki Ypiresia Elladas [National Statistical Service of Greece] (ESYE). 1972b. Plithismos tis Ellados kata tin apografin 
tis 14 Martiou 1971 [The population of Greece of the 14th March 1971 census]. ESYE, Athens, Greece.

Ethniki Statistiki Ypiresia Elladas [National Statistical Service of Greece] (ESYE). 1979. Apotelesmata tis apografis georgiasktinotrofias tis 14 Martiou 1971 [Results of the agriculturelivestock census of 14th March 1971]. ESYE, Athens, Greece.

Ethniki Statistiki Ypiresia Elladas [National Statistical Service of Greece] (ESYE). 1991. Apotelesmata tis apografis plithismoukatoikion tis 5 Apriliou 1981 [The population-housing census results of 5th April 1981]. ESYE, Athens, Greece.

Ethniki Statistiki Ypiresia Elladas [National Statistical Service of Greece](ESYE). 1994. Pragmatikos plithismos tis Ellados kata tin apografi tis 17 Martiou 1991 [Real population of Greece in the census of 17th March 1991]. ESYE, Athens, Greece.

Ethniki Statistiki Ypiresia Elladas [National Statistical Service of Greece](ESYE). 1995. Katanomi ektaseos tis Ellados kata vasikes katigories hriseos (Proapografika stoiheia apografis georgiasktinotrofias tou etous 1991) [The distribution of the country's area by main categories of land use (Precensus data of agriculturelivestock census of 1991)]. ESYE, Athens, Greece.

Ethniki Statistiki Ypiresia Elladas [National Statistical Service of Greece] (ESYE). 1998. Apotelesmata tis apografis georgiasktinotrofias tis 17 Martiou 1991 [Results of the agriculturelivestock census of 17th March 1991]. ESYE, Athens, Greece.

Ethniki Statistiki Ypiresia Elladas [National Statistical Service of Greece] (ESYE). 2003. Apotelesmata apografis georgiasktinotrofias 2000-2001 [Results of the agriculture-livestock census 2000-2001]. ESYE, Athens, Greece.

Ethniki Statistiki Ypiresia Elladas [National Statistical Service of Greece] (ESYE). 2004. Monimos plithismos tis Ellados, Apografi 2001 [Permanent population of Greece, census 2001]. ESYE, Athens, Greece.

Filed, J. 2003. Social capital. Key Ideas series, Routledge, London, UK.

Fisher, R. 2013. "A gentleman's handshake": the role of social capital and trust in transforming information into usable knowledge. Journal of Rural Studies 31:13-22. http://dx.doi. org/10.1016/j.jrurstud.2013.02.006

Folke, C., S. R. Carpenter, B. Walker, M. Scheffer, T. Chapin, and J. Rockström. 2010. Resilience thinking: integrating resilience, adaptability and transformability. Ecology and Society 15(4): 20. [online]URL: http://www.ecologyandsociety.org/vol15/iss4/art20/

Grimm, V., and C. Wissel. 1997. Babel, or the ecological stability discussions: an inventory and analysis of terminology and a guide for avoiding confusion. Oecologia 109:323-334. http://dx.doi. org/10.1007/s004420050090

Grove, A. T., and O. Rackham. 2001. The nature of Mediterranean Europe: an ecological history. Yale University Press, New Haven, Connecticut, USA.

Grumbine, R. E. 1994. What is ecosystem management? Conservation Biology 8:27-38. http://dx.doi.org/10.1046/ j.1523-1739.1994.08010027.x

Hoogesteger, J. 2013. Transforming social capital around water: water user organizations, water rights, and nongovernmental organizations in Cangahua, the Ecuadorian Andes. Society \& Natural Resources 26(1):60-74. http://dx.doi.org/10.1080/08941$\underline{920.2012 .689933}$

Hostert, P., A. Röder, J. Hill, T. Udelhoven, and G. Tsiourlis. 2003. Retrospective studies of grazing-induced land degradation: a case study in central Crete, Greece. International Journal of Remote Sensing 24:4019-4034. http://dx.doi.org/10.1080/0143116031000103844

Iosifides, T., M. Lavrentiadou, E. Petracou, and A. Kontis. 2007. Forms of social capital and the incorporation of Albanian immigrants in Greece. Journal of Ethnic and Migration Studies 33:1343-1361. http://dx.doi.org/10.1080/13691830701614247

Jackson, W. A. 2009. Economics, culture and social theory. Elgar, Cheltenham, UK. http://dx.doi.org/10.4337/9781849802116

Jones, N., C. Malesios, T. Iosifides, and C. M. Sophoulis. 2008. Social capital in Greece: measurement and comparative perspectives. South European Society and Politics 13:175-193. http://dx.doi.org/10.1080/13608740802156687

Karametou, P., and C. Apostolopoulos. 2010. The causal nexus between social capital and local development in mountain rural Greece. International Journal of Social Inquiry 3:29-66.

Kinzig, A. P., P. Ryan, M. Etienne, H. Allison, T. Elmqvist, and B. H. Walker. 2006. Resilience and regime shifts: assessing cascading effects. Ecology and Society 11(1): 20. [online] URL: http://www.ecologyandsociety.org/vol11/iss1/art20/

Kizos, T., T. Plieninger, and H. Schaich. 2013. "Instead of 40 sheep there are 400": traditional grazing practices and landscape change in Western Lesvos, Greece. Landscape Research 38:476-498. http://dx.doi.org/10.1080/01426397.2013.783905

Kloutsinioti, O. 1998. Chorotaksiko sxedio Perifereias Kritis [Spatial plan of the region of Crete]. Ministry for the Environment, Physical Planning and Public Works, Athens, Greece.

Larsen, L., S. L. Harlan, B. Bolin, E. Hackett, D. Hope, A. Kirby, A. Nelson, T. R. Rex, and S. Wolf. 2004. Bonding and bridging: understanding the relationship between social capital and civic action. Journal of Planning Education and Research 24:64-77. http://dx.doi.org/10.1177/0739456X04267181

le Polain de Waroux, Y., and E. F. Lambin. 2012. Monitoring degradation in arid and semi-arid forests and woodlands: the case of the argan woodlands (Morocco). Applied Geography 32:777-786. http://dx.doi.org/10.1016/j.apgeog.2011.08.005

Liodakis, G. 2000. O agrotikos tomeas tis Kritis: Problimata kai prooptikes [The farming sector of Crete: problems and prospects]. Sciences Department, Technical University of Crete, Chania, Greece.

Lorent, H., R. Sonnenschein, G. M. Tsiourlis, P. Hostert, and E. Lambin. 2009. Livestock subsidies and rangeland degradation in central Crete. Ecology and Society 14(2): 41. [online] URL: http:// www.ecologyandsociety.org/vol14/iss2/art41/

Louhaichi, M., and A. Tastad. 2010. The Syrian steppe: past trends, current status, and future priorities. Rangelands 32:2-7. http://dx.doi.org/10.2111/1551-501X-32.2.2

Lyrintzis, G., and V. Papanastasis. 1995. Human activities and their impact on land degradation - Psilorites mountain in Crete: 
a historical perspective. Land Degradation \& Development 6:79-93. http://dx.doi.org/10.1002/ldr.3400060203

Ohno, T., T. Tanaka, and M. Sakagami. 2010. Does social capital encourage participatory watershed management? An analysis using survey data from the Yodo River watershed. Society \& Natural Resources 23(4):303-321. http://dx.doi.org/10.1080/08941920802078224

Pahl-Wostl, C. 2009. A conceptual framework for analysing adaptive capacity and multi-level learning processes in resource governance regimes. Global Environmental Change 19:354-365. http://dx.doi.org/10.1016/j.gloenvcha.2009.06.001

Pahl-Wostl, C., M. Craps, A. Dewulf, E. Mostert, D. Tabara, and T. Taillieu. 2007. Social learning and water resources management. Ecology and Society 12(2): 5. [online] URL: http:// www.ecologyandsociety.org/vol12/iss2/art5

Papadopoulos, D. 1999. Sti skia tou dimosiou diakritikou kefalaiou: mia ekdoxi gia tin ipovathmisi tou anaptiskiakou rolou ton geoponon tou Dimosiou (1981-1994). Pages 237-266 in C. Kassimis and L. Louloudis, editors. Ipaithros Chora: I Elliniki Agrotiki Koinonia sto telos tou eikostou aiona. Plehron, Athens, Greece.

Papanastasis, V., and D. Chouvardas. 2005. Application of the state-and-transition approach to conservation management of a grazed Mediterranean landscape in Greece. Israel Journal of Plant Sciences 53:191-202.

Paraskevopoulos, C. J. 2007. Social capital and public policy in Greece. GreeSE Paper No. 9, Hellenic Observatory Papers on Greece and Southeast Europe, The Hellenic Observatory, London School of Economics and Political Science, London, UK.

Resilience Alliance. 2007. Assessing resilience in social-ecological systems. A workbook for scientists. Resilience Alliance. [online] URL: http://www.resalliance.org/srv/file.php/210

Reynolds, J. F., A. Grainger, D. M. Stafford Smith, G. Bastin, L. Garcia-Barrios, R. J. Fernández, M. A. Janssen, N. Jürgens, R. J. Scholes, A. Veldkamp, M. M. Verstraete, G. Von Maltitz, and P. Zdruli. 2011. Scientific concepts for an integrated analysis of desertification. Land Degradation \& Development 22:166-183. http://dx.doi.org/10.1002/ldr.1104

Reynolds, J. F., D. M. S. Smith, E. F. Lambin, B. L. Turner II, M. Mortimore, S. P. J. Batterbury, T. E. Downing, H. Dowlatabadi, R. J. Fernández, J. E. Herrick, E. Huber-Sannwald, H. Jiang, R. Leemans, T. Lynam, F. T. Maestre, M. Ayarza, and B. Walker. 2007. Global desertification: building a science for dryland development. Science 316:847-851. http://dx.doi.org/10.1126/ science. 1131634

Ruben, R., and J. Heras. 2012. Social capital, governance and performance of Ethiopian coffee cooperatives. Annals of Public and Cooperative Economics 83(4):463-484. http://dx.doi. org/10.1111/j.1467-8292.2012.00473.x

Salmon, T. 1995. The unwritten places. Lycabettus, Athens, Greece.

Scheffer, M., S. R. Carpenter, T. M. Lenton, J. Bascompte, W. Brock, V. Dakos, J. van de Koppel, I. A. van de Leemput, S. A. Levin, E. H. van Nes, M. Pascual, and J. Vandermeer. 2012.
Anticipating critical transitions. Science 338:344-348. http://dx. doi.org/10.1126/science. 1225244

Scheffer, M., and F. R. Westley. 2007. The evolutionary basis of rigidity: locks in cells, minds, and society. Ecology and Society 12 (2): 36. [online] URL: http://www.ecologyandsociety.org/vol12/ iss $2 / \operatorname{art} 36$

Scheffer, M., F. Westley, and W. Brock. 2003. Slow response of societies to new problems: causes and costs. Ecosystems 6:493-502. http://dx.doi.org/10.1007/PL00021504

Slimani, H., A. Aidoud, and F. Rozé. 2010. 30 years of protection and monitoring of a steppic rangeland undergoing desertification. Journal of Arid Environments 74:685-691. http:// dx.doi.org/10.1016/j.jaridenv.2009.10.015

Strunz, S. 2012. Is conceptual vagueness an asset? Arguments from philosophy of science applied to the concept of resilience. Ecological Economics 76:112-118. http://dx.doi.org/10.1016/j. ecolecon.2012.02.012

Swinton, S. M. 2000. More social capital, less erosion: evidence from Peru's Antiplano. Paper presented at the Annual Meeting of American Agricultural Economics Association, Tampa, FL, USA, July 30-August 2.

Tsantiropoulos, A. 2010. I Venteta sti Sigxroni Orini Kriti [Venteta in modern mountainous Crete]. Second edition. Plethron, Athens, Greece.

Tschopp, R., A. Aseffa, E. Schelling, and J. Zinsstag. 2010. Farmers' perceptions of livestock, agriculture, and natural resources in the rural Ethiopian Highlands. Mountain Research and Development 30:381-390. http://dx.doi.org/10.1659/MRDJOURNAL-D-09-00072.1

Tuvendal, M., and T. Elmqvist. 2011. Ecosystem services linking social and ecological systems: river brownification and the response of downstream stakeholders. Ecology and Society 16(4): 21. http://dx.doi.org/10.5751/ES-04456-160421

Walker, B., C. S. Holling, S. R. Carpenter, and A. Kinzig. 2004. Resilience, adaptability and transformability in social-ecological systems. Ecology and Society 9(2): 5. [online] URL: http://www. ecologyandsociety.org/vol9/iss2/art5/

Westley, F., S. R. Carpenter, W. A. Brock, C. S. Holling, and L. H. Gunderson. 2002. Why systems of people and nature are not just social and ecological systems. Pages 103-120 in L. H. Gunderson and C. S. Holling, editors. Panarchy: understanding transformations in human and natural systems. Island, Washington, D.C., USA. 